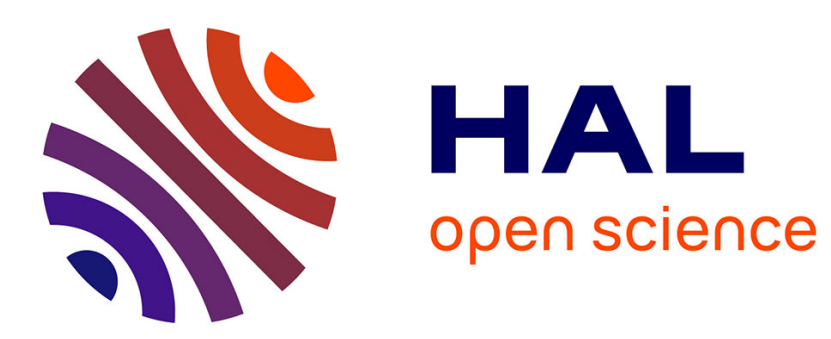

\title{
THERMAL LENS SPECTROMETRY AS A DETECTOR FOR FLOW INJECTION ANALYSIS OF LANTHANIDES
}

\author{
A. Chartier, C. Fox, J. Georges
}

\section{- To cite this version:}

A. Chartier, C. Fox, J. Georges. THERMAL LENS SPECTROMETRY AS A DETECTOR FOR FLOW INJECTION ANALYSIS OF LANTHANIDES. Journal de Physique IV Proceedings, 1991, 01 (C7), pp.C7-703-C7-703. 10.1051/jp4:19917188 . jpa-00250867

\section{HAL Id: jpa-00250867 https://hal.science/jpa-00250867}

Submitted on 1 Jan 1991

HAL is a multi-disciplinary open access archive for the deposit and dissemination of scientific research documents, whether they are published or not. The documents may come from teaching and research institutions in France or abroad, or from public or private research centers.
L'archive ouverte pluridisciplinaire HAL, est destinée au dépôt et à la diffusion de documents scientifiques de niveau recherche, publiés ou non, émanant des établissements d'enseignement et de recherche français ou étrangers, des laboratoires publics ou privés. 


\title{
THERMAL LENS SPECTROMETRY AS A DETECTOR FOR FLOW INJECTION ANALYSIS OF LANTHANIDES
}

\author{
A. CHARTIER, C.G. FOX and J. GEORGES \\ Laboratoire des Sciences Analytiques (U.A. 435), 43 boulevard du 11 novembre 1918, \\ F-69622 Villeurbanne cedex, France
}

The increasing interest of lanthanides in technological industries has made it necessary to develop fast and sensitive methods for their determination, especially in trace quantities. The main problem encountered in the detection of lanthanides is due to their low absorptivities, which results in a poor sensitivity of conventional spectrophotometric method, such as UV-visible absorption and fluorescence.

The detection of these elements can be improved both by complexing the ions with highly absorbing organic ligands and by using laser-based spectrophotometric methods. The high power density and the focusing ability of laser beams can greatly enhance the detection sensitivity of small volume samples.

This work describes the determination of lanthanides as their chelates by using flow injection analysis and thermal lens detection. The complexing reagent 4-(2-pyridylazo)resorcinol ( PAR ) was used leading to stable complexes with absorptivities about $10^{3}$ times greater than those of the ions. The complexes formed are non-fluorescent and thus can be readily detected by a photothermal method, such as thermal lens spectrometry.

Two specitic problems could arise when using thermal lens detection in place of conventional spectrophotometry. First, the analytical thermal lens signal may be disturbed by the large background caused by ligand absorption at the detection wavelength. This could be solved either by a decrease in the PAR concentration or by a modification of the flow injection system. Second, the thermal lens signal may be decreased by the flow if the signal rise time is significantly longer than the time required for mass transfer and solution mixing inside the detection cell.

Experiments using $\mathrm{cw}$ - or pulsed- laser excitation together with different flow through cell configurations will be investigated with respect to signal intensity and flow effect. The results will be compared with those obtained with a conventional spectrophotometric detector. 